\title{
Inovasi Pelayanan Dinas Kearsipan dan Perpustakaan Kabupaten Cianjur di Masa Pandemi Covid-19
}

\author{
${ }^{1}$ Putri Nur Nabihatul Ghofilah, ${ }^{2}$ Sukaesih, ${ }^{3}$ Evi Nursanti Rukmana, \\ ${ }^{4}$ Asep Saeful Rohman \\ ${ }^{1,2,3,4}$ Program Studi Perpustakaan dan Sains Informasi Universitas \\ Padjadjaran \\ E-mail: ${ }^{1}$ putri19030@ mail.unpad.ac.id, ${ }^{2}$ sukaesih@unpad.ac.id, \\ 3 evi.nursanti.r@gmail.com, ${ }^{4}$ asep.saeful@unpad.ac.id
}

\begin{abstract}
The presence of Covid-19, which is currently a global pandemic, has had a huge influence on various aspects of activities in human life, many activities have been registered including library service activities. There is a policy of working from home as a step to anticipate the transmission of the corona virus, which causes library employees to work from home and carry out various activities boldly. So that the library cannot provide services to the community directly. This study aims to see the innovations that the Office of Archives and Libraries of Cianjur Regency have in providing services to the public or library users during the Covid-19 pandemic. The method used is descriptive qualitative method. The data technique used is literature study, observation, interviews, and documentation. Meanwhile, the data analysis used was data reduction, data presentation, and data retrieval. The results in this study indicate that due to the Covid-19 pandemic, the library service system has changed. Various kinds of face-to-face services and switching through digital services. To deal with this situation, the Office of Archives and Libraries of Cianjur Regency is trying to create new innovations in order to continue to provide sources of information to the public. From the research, it can be denied that the Office of Archives and Libraries of Cianjur Regency does not yet have digital services and can only access digital services in the form of the Ipusnas application and the CANDIL application to the public.
\end{abstract}

Keywords: Covid-19 Pandemic; Libraries; Innovation; Services

\section{Abstrak}

Kehadiran covid-19 yang dianggap sebagai sebuah pandemi global saat ini telah memberikan pengaruh yang sangat besar terhadap berbagai aspek kegiatan dalam kehidupan manusia, banyak kegiatan-kegiatan yang

Tik Ilmeu : Jurnal Ilmu Perpustakaan dan Informasi IAIN Curup | p-issn: 2580-3654; e-issn:2580-3662

DOI: $10.29240 /$ tik.v5i1.2121 
terpaksa dihentikan termasuk kegiatan layanan perpustakaan. Adanya kebijakan work from home sebagai langkah untuk mengantisipasi penularan virus corona, menyebabkan para pegawai perpustakaan harus bekerja dari rumah dan melakukan berbagai kegiatannya secara daring. Sehingga perpustakaan tidak dapat memberikan layanan kepada masyarakat secara langsung. Penelitian ini bertujuan untuk mengetahui inovasi yang dimiliki Dinas Kearsipan dan Perpustakaan Kabupaten Cianjur dalam memberikan pelayanan kepada masyarakat atau pengguna perpustakaan di masa pandemi covid-19. Metode yang digunakan adalah metode kualitatif deskriptif. Teknik pengumpulan data yang digunakan adalah studi kepustakaan, observasi, wawancara, dan dokumentasi. Sedangkan analisis data yang digunakan adalah reduksi data, penyajian data, dan penarikan kesimpulan. Hasil dalam penelitian ini menunjukkan bahwa akibat adanya pandemi covid-19 ini membuat sistem layanan perpustakaan mengalami perubahan. Berbagai macam layanan secara tatap muka dibatasi dan beralih melalui layanan digital. Untuk menghadapi situasi tersebut, Dinas Kearsipan dan Perpustakaan Kabupaten Cianjur berupaya menciptakan inovasi baru agar tetap memberikan sumber informasi kepada masyarakat. Dari penelitian dapat disimpulkan bahwa Dinas Kearsipan dan Perpustakaan Kabupaten Cianjur belum memiliki layanan digital dan hanya dapat merekomendasikan akses layanan digital berupa aplikasi Ipusnas dan aplikasi CANDIL kepada masyarakat.

Kata Kunci: Pandemi Covid-19; Perpustakaan; Inovasi; Layanan

\section{A. PENDAHULUAN}

Pada saat ini seluruh dunia sedang disibukkan oleh sebuah pandemi. Pandemi ini bernama Coronavirus Disease atau yang dikenal dengan Covid-19 ialah sebuah wabah penyakit jenis baru yang pada awalnya terkonfirmasi di kota Wuhan, provinsi Hubei, China bulan Desember tahun 2019. Adanya virus corona ini ditandai dengan gejala ringan dan gejala berat seperti flu, batuk kering, demam, nyeri tenggorokan, diare, hilangnya indera perasa atau penciuman, serta sesak nafas bahkan dapat berakibat kematian bagi seseorang apabila terjangkit oleh virus ini (Azanella, 2021). Virus corona ini juga dapat menular dengan sangat cepat melalui droplet atau percikan air liur dari mulut atau hidung seseorang pada saat sedang bersin atau batuk. 
Perkembangan kasus virus corona di dunia pada saat ini memperlihatkan angka yang cukup signifikan hal ini dikarenakan penyebarannya telah dirasakan oleh berbagai negara, termasuk negara Indonesia. Kasus pertama Covid-19 di Indonesia pertama kali dikonfirmasi pada tanggal 2 Maret 2020 oleh Presiden Joko Widodo, yang dimana terdiri dari dua orang di daerah Depok yang terjangkit virus corona dimana mereka telah berkontak langsung dengan orang Jepang yang menetap di Malaysia saat berada di sebuah pesta dansa (Lies et al., 2020).

Dengan adanya pandemi tersebut pemerintah kemudian menghimbau kepada masyarakat untuk mematuhi protokol kesehatan dengan selalu menggunakan masker, giat mencuci tangan dengan sabun, dan selalu menjaga jarak dengan orang lain. Pemerintah juga mengajak masyarakat untuk tetap berada di rumah masing-masing dalam rentang waktu yang panjang serta mengurangi kegiatan-kegiatan diluar rumah yang tidak begitu penting demi memutus mata rantai penyebaran covid-19. Kemudian pada tanggal 31 Maret 2020 Presiden Jokowi mengumumkan kepada masyarakat Indonesia mengenai kebijakan yang akan diambilnya dalam menyikapi covid-19 sebagai sebuah pandemi global, yakni dengan menerapkan Pembatasan Sosial Berskala Besar (PSBB) yang merupakan suatu kebijakan yang dibentuk guna mencegah tersebar luasnya virus dan untuk membatasi kegiatan-kegiatan yang dimiliki oleh masyarakat yang ada di beberapa daerah yang diduga terinfeksi virus corona. Kebijakan tersebut sesuai dengan yang tercantum dalam Peraturan Pemerintah (PP) Nomor 21 Tahun 2020 yaitu mengenai "Pembatasan Sosial Berskala Besar Dalam Rangka Percepatan Penanganan Corona Virus Disease 2019 (COVID-19)" (Ristyawati, 2020).

Penyebaran kasus positif covid-19 di Indonesia yang pada setiap harinya mengalami kenaikan dengan begitu pesat mengakibatkan kondisi ini pun sangat berbahaya sehingga membutuhkan penanganan yang serius dan cepat, karena pandemi covid-19 di Indonesia sendiri telah mempengaruhi terhadap sejumlah aspek multi dimensional seperti dibidang ekonomi, sosial, budaya dan politik (MS \& Rizaldi, 2020). Selain itu juga telah mempengaruhi terhadap aspek pendidikan salah satunya bagi lembaga informasi atau perpustakaan.

Perpustakaan adalah salah satu pusat informasi yang mempunyai fungsi sebagai agen perubahan (agent of change). Perpustakaan tidak hanya hadir sebagai tempat untuk menyimpan koleksi bahan bacaan, melainkan 
perpustakaan mampu memberikan informasi-informasi baik yang berupa ilmu pengetahuan, teknologi maupun kebudayaan. Dengan kehadiran perpustakaan ini diharapkan dapat membentuk pola pikir masyarakat yang kritis. Oleh sebab itu, perpustakaan memiliki tanggung jawab atas informasi-informasi yang terkandung di dalam koleksi bacaan yang dimilikinya baik dalam proses pendidikan, informasi maupun rekreasi untuk masyarakat. Sulistyo-Basuki (1991:3) mendefinisikan perpustakaan sebagai "sebuah ruangan, bagian sebuah gedung ataupun gedung itu sendiri yang digunakan untuk menyimpan buku dan terbitan lainnya yang biasanya disimpan menurut tata susunan tertentu untuk digunakan oleh pembaca, bukan untuk dijual". Definisi perpustakaan lainnya, menurut Trimo (1987;3) dalam Encyclopaedia Americana ialah "kumpulan dari buku-buku dan bentuk-bentuk rekaman lain yang disimpan, dikelola dan diinterpretasikan untuk disebarluaskan dan digunakan oleh masyarakat bagi keperluan informasi, pengetahuan, rekreasi, dan rasa estetika" (Sukaesih \& Winoto, 2019).

Terdapat beberapa macam perpustakaan yang dapat dikategorikan berdasarkan fungsi yang dimiliki salah satu diantaranya yakni perpustakaan umum. Menurut Undang-Undang RI Nomor 43 tahun 2007 mengenai perpustakaan bahwa yang dimaksud dengan perpustakaan umum ialah "perpustakaan yang diselenggarakan pemerintah, pemerintah daerah dan/atau masyarakat yang layanannya diperuntukan bagi masyarakat luas di wilayahnya masing-masing". Perpustakaan umum memiliki fungsi sebagai pusat pengetahuan dan informasi, selain itu perpustakaan umum juga dapat dijadikan sebagai tempat yang strategis bagi suatu kelompok berkumpul untuk sekedar bertukar pikiran baik itu perihal urusan kerja, tugas, maupun permasalahan yang ada dalam kehidupan sehari-hari (Ayuningtyas, 2015). Perpustakaan umum sendiri dituntut untuk dapat memberikan layanan kepada masyarakat secara umum dengan tanpa membedakan latar belakang dari masing-masing masyarakat tersebut seperti usia, pendidikan, status sosial, agama maupun ras.

Di tengah pandemi seperti saat ini sangat tidak memungkinkan bagi suatu perpustakaan untuk membuka layanan seperti saat sebelum terjadi pandemi yang dimana dapat melayani masyarakat atau penggunanya secara tatap muka atau secara langsung. Dinas Kearsipan dan Perpustakaan Kabupaten Cianjur merupakan salah satu perpustakaan umum daerah yang juga ikut terkena imbas. Semenjak hadirnya pandemi covid-19, Dinas Kearsipan dan Perpustakaan Kabupaten Cianjur terpaksa menghentikan 
segala aktivitasnya dalam melakukan pelayanan secara langsung kepada masyarakat terlebih khususnya dalam hal peminjaman dan pengembalian koleksi buku. Selain itu, menyebabkan jumlah pengunjung Dinas Kearsipan dan Perpustakaan Kabupaten Cianjur pun mengalami penurunan secara drastis berbeda dengan sebelum adanya pandemi ini menyebar, yang dimana ramai dikunjungi oleh para pengunjung baik dari anak sekolah, kuliahan maupun masyarakat umum.

Hal tersebut disebabkan karena adanya sebuah kebijakan baru yang diterapkan oleh pemerintah yaitu kebijakan work from home (WFH) yang menuntut para pegawai perpustakaan untuk melakukan pekerjaan di rumah dan melakukan berbagai kegiatannya secara daring. Sehingga membuat para pustakawan Dinas Kearsipan dan Perpustakaan Kabupaten Cianjur pun tidak dapat memberikan pelayanan secara optimal dalam memenuhi kebutuhan pemustaka terhadap informasi yang ada di perpustakaan. Munculnya pandemi covid-19 ini membuat perpustakaan harus mengikuti kebijakan yang dianjurkan oleh pemerintah, anjuran tersebut sangat penting dan perlu dilakukan sebagai langkah untuk mengantisipasi penularan virus covid-19 dan agar perpustakaan sendiri tidak menjadi penyebab munculnya klaster baru.

Hal tersebut disebabkan karena adanya sebuah kebijakan baru yang diterapkan oleh pemerintah yaitu kebijakan work from home (WFH) yang menuntut para pegawai perpustakaan untuk melakukan pekerjaan di rumah dan melakukan berbagai kegiatannya secara daring. Sehingga membuat para pustakawan Dinas Kearsipan dan Perpustakaan Kabupaten Cianjur pun tidak dapat memberikan pelayanan secara optimal dalam memenuhi kebutuhan pemustaka terhadap informasi yang ada di perpustakaan. Munculnya pandemi covid-19 ini membuat perpustakaan harus mengikuti kebijakan yang dianjurkan oleh pemerintah, anjuran tersebut sangat penting dan perlu dilakukan sebagai tindakan guna mengantisipasi penularan virus corona dan agar perpustakaan sendiri tidak menjadi penyebab munculnya klaster baru.

Akan tetapi, IFLA (International Federation of Library Associations and Institutions) sebagai Lembaga Internasional pada bidang perpustakaan memberikan izin kepada seluruh perpustakaan untuk memberikan pelayanan pada saat berjalannya pandemi (IFLA, 2020 dalam Suharso et al., 2020). Maka dari itu, untuk dapat terus melayani masyarakat atau pengguna di tengah pandemi berlangsung perpustakaan perlu 
menciptakan sebuah strategi baru yang berupa inovasi-inovasi baru dengan menyesuaikan terhadap kebutuhan para pengguna akan informasi di masa pandemi covid-19. Dengan mengikuti adaptasi kebiasaan baru atau new normal serta menerapkan protokol kesehatan yang baik, diarenakan kesehatan pemustaka dan pustakawan sendiri ialah yang paling utama.

Berdasarkan pemaparan latar belakang yang telah penulis lakukan diatas, terdapat beberapa rumusan masalah yang telah penulis tetapkan sebagai berikut : (1) Bagaimana kebijakan yang dimiliki oleh Dinas Kearsipan dan Perpustakaan Kabupaten Cianjur dalam memberikan layanan kepada masyarakat atau penggunanya?, (2) Bagaimana kondisi Dinas Kearsipan dan Perpustakaan Kabupaten Cianjur saat ini setelah adanya pandemi covid-19, (3) Pelayanan atau kegiatan apa sajakah yang diberikan oleh Dinas Kearsipan dan Perpustakaan Kabupaten Cianjur kepada masyarakat atau pengguna perpustakaan sebelum dan di tengah masa pandemi covid-19, (4) Bagaimana dampak yang dirasakan bagi Dinas Kearsipan dan Perpustakaan Kabupaten Cianjur dari adanya perubahan yang terjadi akibat pandemi covid-19 ini, dan (5) Bagaimanakah inovasi yang dimiliki Dinas Kearsipan dan Perpustakaan Kabupaten Cianjur dalam memberikan pelayanan kepada masyarakat atau pengguna perpustakaan di masa pandemi covid-19 ini.

Dari penerapan rumusan masalah di atas, penulis memiliki beberapa tujuan diantaranya yakni : (1) Untuk mengetahui kebijakan yang dimiliki oleh Dinas Kearsipan dan Perpustakaan Kabupaten Cianjur dalam memberikan layanan kepada masyarakat atau penggunanya?, (2) Untuk mengetahui kondisi Dinas Kearsipan dan Perpustakaan Kabupaten Cianjur saat ini setelah adanya pandemi covid-19, (3) Untuk mengetahui pelayanan atau kegiatan apa sajakah yang diberikan oleh Dinas Kearsipan dan Perpustakaan Kabupaten Cianjur kepada masyarakat atau pengguna perpustakaan sebelum dan di tengah masa pandemi covid-19, (4) Untuk mengetahui dampak yang dirasakan bagi Dinas Kearsipan dan Perpustakaan Kabupaten Cianjur dari adanya perubahan yang terjadi akibat pandemi covid-19 ini, dan (5) Untuk mengetahui inovasi yang dimiliki Dinas Kearsipan dan Perpustakaan Kabupaten Cianjur dalam memberikan pelayanan kepada masyarakat atau pengguna perpustakaan di masa pandemi covid-19 ini.

Pada penelitian ini penulis menggunakan metode penelitian kualitatif deskriptif. Metode pendekatan kualitatif deskriptif ialah suatu 
metode pengolahan data yang dilakukan dengan menganalisis faktor-faktor yang berkaitan dengan objek penelitian dengan penyajian data secara lebih mendalam terhadap suatu objek penelitian (Prabowo \& Heriyanto, 2013). Melalui metode penelitian ini penulis sebagai peneliti lebih memberikan gambaran mengenai inovasi Dinas Kearsipan dan Perpustakaan Kabupaten Cianjur guna melayani masyarakat atau pengguna perpustakaan di masa pandemi sedang berlangsung. Yang menjadi subjek pada penelitian ini adalah salah satu pustakawan Dinas Kearsipan dan Perpustakaan Kabupaten Cianjur yang bernama Ibu Wanti Agustin, dan objeknya adalah inovasi Dinas Kearsipan dan Perpustakaan Kabupaten Cianjur guna melayani masyarakat atau pengguna perpustakaan di masa pandemi sedang berlangsung. Penelitian ini berlokasi di Dinas Kearsipan dan Perpustakaan Kabupaten Cianjur, Jalan Slamet Riyadi No.1, Jawa Barat. Adapun waktu penelitian dilaksanakan hari Senin, 02 November 2020 pukul 11.20 WIB.

Teknik pengumpulan data ialah sebuah proses yang sangat penting guna memperoleh data di dalam suatu penelitian, data tersebut mencakup data primer yang diperoleh dari hasil wawancara dengan informan dan data sekunder yang diperoleh dari suatu dokumen yang berhubungan dengan penelitian. Dalam penelitian yang penulis lakukan terdapat beberapa teknik pengumpulan data yang diantaranya adalah penulis melakukan studi kepustakaan dengan mempelajari beberapa teori yang terdapat pada buku, artikel, makalah, jurnal, dan mencari beberapa data lain melalui internet untuk menambah wawasan penulis yang berhubungan dengan inovasi layanan perpustakaan di masa pandemi covid-19. Selain itu, penulis melakukan studi lapangan dengan pengamatan secara langsung ke tempat penelitian guna mendapatkan data yang dibutuhkan. Terdapat beberapa teknik pengumpulan data dalam melakukan studi lapangan, diantaranya sebagai berikut : (1) Observasi, yakni teknik pengumpulan data penelitian yang dilakukan melalui survei secara langsung guna memperoleh informasi dan data yang lengkap serta akurat. (2) Wawancara, yakni teknik pengumpulan data yang dilaksanakan melalui cara tanya jawab kepada informan mengenai pembahasan yang sedang diteliti, sehingga penulis mampu menerima informasi yang relevan dan lengkap. Dalam implementasinya, penulis melakukan observasi secara langsung ke Dinas Kearsipan dan Perpustakaan Kabupaten Cianjur dan melakukan wawancara terstruktur kepada salah satu pustakawannya dengan berdasar pada susunan pertanyaan-pertanyaan yang sudah disiapkan. 
Dalam melakukan proses analisis data penulis menggunakan model analisis Miles and Huberman (2005:15-19), model ini meliputi pengumpulan data, yaitu menghimpun data pada lokasi penelitian dengan melakukan observasi secara langsung, lalu melakukan wawancara kepada informan, kemudian penulis melakukan dokumentasi dengan menentukan strategi pengumpulan data yang dianggap valid guna memperdalam data serta menentukan fokus pada proses pengumpulan data yang akan dilakukan selanjutnya. Yang pertama reduksi data, yakni suatu proses yang mencakup seleksi, pemfokusan, pengabstrakan, dan transformasi data kasar yang terdapat di tempat penelitian, dan dilanjutkan pada waktu pengumpulan data. Dengan demikian, proses reduksi data dilakukan pada saat penulis memfokuskan lokasi penelitian. Yang kedua penyajian data, yakni suatu rangkaian organisasi informasi yang memungkinkan dilaksanakannya penelitian. Penyajian data ini didapatkan dari berbagai macam jenis jaringan kerja yang berkaitan dengan kegiatan atau tabel. Yang ketiga penarikan kesimpulan, dalam pengumpulan data penulis harus memahami terhadap sesuatu yang sedang diteliti secara langsung di lapangan dengan membentuk pola-pola petunjuk serta sebab akibat (Arista, 2019).

\section{B. HASIL DAN PEMBAHASAN}

Dari observasi dan wawancara yang telah dilakukan, penulis dapat menguraikan tentang inovasi pelayanan perpustakaan di masa pandemi covid-19. Pada penelitian ini pula, penulis memperoleh hasil mengenai inovasi pelayanan perpustakaan yang dimiliki Dinas Kearsipan dan Perpustakaan Kabupaten Cianjur di masa pandemi covid-19.

Perpustakaan daerah merupakan fasilitas khusus yang telah disediakan pemerintah guna membantu masyarakat dalam memenuhi kebutuhannya terhadap informasi, oleh karena itu siapapun dapat memanfaatkan dan mendapat layanan perpustakaan baik itu dari kalangan pelajar pendidikan anak usia dini (PAUD) atau taman kanak-kanak (TK), sekolah dasar (SD), sekolah menengah pertama (SMP), sekolah menengah atas (SMA), mahasiswa, karyawan maupun masyarakat umum yang berada di wilayahnya. Seperti yang kita ketahui bahwa pada prinsipnya setiap perpustakaan tentu mempunyai sebuah kebijakannya masing-masing dalam melayani masyarakat atau penggunanya, sebagaimana dapat dilihat bahwa di Dinas Kearsipan dan Perpustakaan Kabupaten Cianjur memiliki beberapa kebijakan termasuk kebijakan peminjaman atau pengembalian 
buku atau yang sering disebut dengan layanan sirkulasi. Dinas Kearsipan dan Perpustakaan Kabupaten Cianjur memiliki berbagai jenis koleksi buku yang dapat dimanfaatkan oleh pengguna yang dimana jenis-jenis koleksi tersebut terdiri dari berbagai disiplin ilmu dengan menggunakan sistem pengelompokkan subyek Dewey Desimal Classification (DDC) mulai dari nomor 000 tentang karya umum sampai dengan nomor 900 tentang sejarah, geografi, dan biografi serta berdasarkan data yang ada sampai dengan tahun 2019 terdapat sebanyak 16.866 judul buku dan 24.494 eksemplar.

Kebijakan yang terdapat di Dinas Kearsipan dan Perpustakaan Kabupaten Cianjur berkaitan dengan pelayanan sirkulasi kepada pengguna yaitu dengan menggunakan sistem pelayanan open access, dengan sitem ini pengguna mampu memilih dan mengambil sendiri koleksi bahan pustaka yang diperlukan secara langsung dan untuk peminjaman buku dikhususkan bagi masyarakat yang telah terdaftar sebagai anggota perpustakaan. Maka dari itu, terdapat beberapa syarat untuk menjadi anggota perpustakaan yaitu masyarakat hanya perlu melampirkan satu lembar fotokopi identitas diri seperti Kartu Tanda Penduduk (KTP), Kartu Pelajar, ataupun Kartu Tanda Mahasiswa (KTM) dan masyarakat tersebut harus berasal dari warga Cianjur, kemudian masyarakat mengisi formulir yang telah disediakan oleh perpustakaan. Adapun hak dan kewajiban yang dapat diperoleh anggota perpustakaan adalah dapat meminjam koleksi bahan pustaka dengan maksimal sebanyak dua buah buku, dengan batas peminjaman selama lima hari dan apabila buku tersebut masih diperlukan maka masyarakat yang menjadi anggota perpustakaan dapat memperpanjang waktu peminjaman dengan maksimal selama dua kali berturut-turut.

Kehadiran covid-19 yang dianggap sebagai sebuah pandemi global saat ini memberikan pengaruh yang begitu besar pada setiap aspek aktivitas manusia, banyaknya kegiatan-kegiatan masyarakat yang terpaksa dihentikan salah satunya yaitu dalam dunia pendidikan termasuk perpustakaan umum daerah yang berada di Cianjur. Pada tanggal 17 Maret 2020 Dinas Kearsipan dan Perpustakaan Kabupaten Cianjur terpaksa menutup sementara layana perpustakaan dan menghentikan segala aktivitas dalam memberikan layanan secara langsung kepada masyarakat termasuk dalam layanan sirkulasi, hal ini dilakukan sesuai dengan perintah dari Bupati Cianjur sebagai langkah dalam mengantisipasi penyebaran covid-19 sebagaimana tertera dalam Surat Edaran Bupati Cianjur Nomor : 848/2755/BKPPD/2020 tentang sistem kerja Aparat Sipil Negara pada masa pelaksanaan pembatasan sosial berskala besar (PSBB) parsial di 
wilayah Kabupaten Cianjur dan memperhatikan sistem kerja Aparat Sipil Negara melalui mekanisme work from home (WFH) di lingkungan pemerintah Kabupaten Cianjur yang telah mengalami beberapa perubahan dan terakhir dengan Surat Edaran Bupati Nomor : 848/2609/BKPPD/2020. Maka hingga saat ini pun Dinas Kearsipan dan Perpustakaan Kabupaten Cianjur masih memberlakukan work from home (WFH) dan belum dapat membuka akses layanan perpustakaan secara langsung kepada masyarakat secara umum dikarenakan belum adanya kebijakan dari pemerintah daerah.

Perpustakaan memiliki salah satu kegiatan yakni melayani masyarakat atau pengguna yang datang langsung ke perpustakaan. Layanan yang paling utama diberikan ialah mengenai bahan pustaka untuk dijadikan bahan bacaan maupun bahan studi. Kegiatan layanan perpustakaan ini dapat dikatakan sebagai aktivitas yang paling pokok dalam perpustakaan karena berfungsi sebagai penghubung antara bahan pustaka dengan pengguna yang membutuhkan guna memaksimalkan pemanfaatan bahan pustaka atau sumber informasi yang terdapat di dalamnya. Dengan adanya layanan perpustakaan ini tentu sangat membantu masyarakat atau pengguna perpustakaan dalam mencari suatu informasi sesuai yang diinginkan dengan cepat, tepat dan akurat. Maka untuk memberikan layanan yang berkualitas perpustakaan harus berorientasi pada kepuasan pengguna dengan terlebih dahulu memahami karakteristik serta kebutuhan pengguna itu seperti apa, supaya perpustakaan pun dapat menyediakan segala informasi yang up to date sesuai dengan keinginan penggunanya.

Dinas Kearsipan dan Perpustakaan Kabupaten Cianjur memiliki berbagai kegiatan dalam memberikan pelayanan kepada para penggunanya salah satunya yaitu rutin melaksanakan kegiatan layanan perpustakaan keliling khusus untuk warga masyarakat yang berada di wilayah yang jauh dengan jangkauan layanan perpustakaan umum baik dari wilayah utara hingga wilayah selatan. Perpustakaan keliling sendiri merupakan layanan eksistensi yang beroperasi dengan membawa berbagai koleksi bacaan untuk melayani masyarakat dari satu tempat ke tempat lain yang belum bisa terjangkau oleh layanan perpustakaan umum. Melalui perpustakaan keliling ini pula masyarakat mampu mendapatkan bahan bacaan yang diinginkan dengan mudah baik untuk meningkatkan minat baca dan mengembangkan kegemarannya terhadap buku.

Seiring berkembangnya paradigma perpustakaan yang berbasis inklusi sosial Dinas Kearsipan dan Perpustakaan Kabupaten Cianjur pun 
telah menjadi bagian dari fasilitator dalam beberapa kegiatan masyarakat yang diantaranya yakni kegiatan tutorial make up Purbasari, tutorial hijab Elzatta dan Zoya, craft class Yundami Gallery, cooking class, pelatihan nge-blog, pelatihan marketing online bersama Bukalapak dan Telkomsel, pelatihan atau pengenalan komputer bagi siswa SMK Dhuafa. Adapun kegiatan pelatihan penggunaan aplikasi SLiMS bagi pengelola perpustakaan sekolah, penyuluhan dagusibu (dapat, gunakan, simpan, buang) dari Ikatan Apoteker Indonesia (IAI), language class (English, Spain, Dutch, Russian, Mandarin, Arabic, etc) bekerjasama dengan Ersan English Course (EEC) dan Best edutainment, Mahasiswa Sastra Rusia Universitas Padjadjaran, Mahasiswa Sastra Mandarin Universitas Muhammadiyah Yogyakarta, staf Dinas Kearsipan dan Perpustakaan, story telling Teh Dini Berkisah, Kelas menulis dan sebagainya.

Semua kegiatan tersebut dapat terselenggarakan dengan baik karena adanya kerjasama antara perpustakaan sebagai fasilitator atau tempat berkegiatan dengan mitra perpustakaan atau yang disebut dengan library supporter untuk berbagi ilmu pengetahuan dan wawasan yang dimiliki kepada masyarakat yang membutuhkannya. Sulistyo Basuki dalam (Sulistyo Basuki, 1993) mendefinisikan kerjasama antar perpustakaan sebagai salah satu kegiatan yang menyertakan dua perpustakaan atau bahkan lebih, dengan dilakukannya kegiatan kerjasama antar perpustakaan tersebut diharapkan dapat menggapai tujuan yang dimiliki oleh setiap perpustakaan secara bersama-sama untuk memenuhi kebutuhan pengguna terhadap sumber informasi. Kerjasama antar perpustkaan juga telah diatur sebagaimana Undang-Undang tentang Perpustakaan No. 43 Tahun 2007 pada bab XI pasal 42, yang berbunyi bahwa "sebuah perpustakaan bisa menjalin kerjasama dengan berbagai pihak guna meningkatkan layanan kepada pemustaka. Peningkatan layanan kepada pemustaka bertujuan untuk meningkatkan jumlah pemustaka yang dapat dilayani dan meningkatkan mutu layanan perpustakaan dengan memanfaatkan sistem jejaring perpustakaan yang berbasis teknologi informasi dan komunikasi" (Meilisa, 2019). Maka dari itu kerjasama yang dilakukan diantara setiap perpustakaan sangatlah penting, selain guna meminimalisir dan melengkapi kekurangan-kekurangan yang dimiliki oleh masing-masing perpustakaan serta dapat pula meningkatkan kualitas pelayanan kepada pengguna perpustakaan dalam memenuhi kebutuhannya terhadap informasi.

Beberapa aspek dalam kehidupan manusia mengalami banyak perubahan akibat adanya wabah virus corona ini, aspek yang mengalami 
perubahan tersebut ialah aspek pelayanan yang dimiliki oleh setiap perpustakaan. Sebagaimana yang dirasakan oleh Dinas Kearsipan dan Perpustakaan Kabupaten Cianjur bahwa mereka saat ini tidak dapat memberikan akses pelayanan secara optimal untuk membantu masyarakat atau pengguna perpustakaan dalam mencari langsung sumber-sumber informasi atau bahan koleksi yang terdapat di perpustakaan. Selain itu, jangkauan pada layanan perpustakaan keliling yang biasanya dilakukan Dinas Kearsipan dan Perpustakaan Kabupaten Cianjur ke berbagai pelosok wilayah terpaksa harus dihentikan atau dibatasi seminimal mungkin. Adapun perbedaan tingkat kunjungan pemustaka yang dialami Dinas Kearsipan dan Perpustakaan Kabupaten Cianjur, dimana pada saat sebelum adanya pandemi covid-19 ini tingkat kunjungan pemustaka ke perpustakaan sendiri sangat ramai dikunjungi oleh pelajar dari berbagai sekolah, mahasiswa, maupun masyarakat umum. Namun di tengah pandemi yang sedang berlangsung ini terjadi penurunan tingkat kunjungan pemustaka secara drastis hal ini disebabkan karena adanya penutupan sementara layanan perpustakaan sampai batas waktu yang belum ditentukan.

Perubahan yang terjadi juga menyebabkan Dinas Kearsipan dan Perpustakaan Kabupaten Cianjur hanya dapat melakukan beberapa kegiatan yang terbatas seperti pada saat melakukan kegiatan kerjasama layanan bahan bacaan dan story telling bagi anak-anak usia sekolah yang terdampak akibat pandemi covid-19 dalam Program BRIMOB Polda Jawa Barat Tahun 2020, yaitu BRAIN (BRIMOB Ramah Anak Indonesia) pada Desa Siaga binaan BRIMOB yang berada di wilayah Jangari Kecamatan MandeCianjur. Lalu melakukan kegiatan pembinaan perpustakaan desa atau pojok baca, bimbingan kepada pengelola perpustakaan desa dalam rangka perlombaan 10 Program PKK Tingkat Provinsi Jawa Barat Tahun 2020 yang dilaksanakan di Desa Leuwikoja Kecamatan Mande yang mewakili Kabupaten Cianjur. Pada kegiatan perlombaan tersebut, Dinas Kearsipan dan Perpustakaan Kabupaten Cianjur menyampaikan serah peminjaman koleksi buku bacaan dan melaksanakan layanan perpustakaan bergerak dengan 'stand by' nya mobil layanan perpustakaan keliling di lokasi. Selain itu, pustakawan bersama Duta Baca perwakilan Cianjur melakukan kegiatan sharing di Instagram Live melalui akun media sosial milik Dinas Kearsipan dan Perpustakaan Kabupaten Cianjur yaitu @disarpus_cianjur, dalam kegiatan sharing tersebut membahas mengenai dampak dari adanya pandemi untuk para ibu yang bekerja dalam pembelajaran online atau daring bagi anak-anak sekolah. 
Ditengah berlangsungnya pandemi covid-19 seperti saat ini bukan berarti perpustakaan harus berdiam diri saja dengan tidak melayani masyarakat, melainkan harus mampu untuk beradaptasi dan menyesuaikan diri dengan menjadi lebih aktif dan berinovatif guna dapat menghadapi situasi tersebut supaya tetap bisa memberikan layanan dengan semaksimal mungkin kepada masyarakat atau pengguna perpustakaan. Umumnya banyak sekali perpustakaan yang ada di Indonesia melakukan perubahan terhadap sistem layanan yang dimilikinya, dengan menerapkan pelayanan yang berbasis teknologi informasi seperti merubah sistem pelayanan yang berasal dari manual menjadi sistem layanan digital, hal ini dikarenakan semakin besarnya tuntutan akan kebutuhan informasi yang dimiliki oleh masyarakat kepada perpustakaan sehingga hampir seluruh perpustakaan pun berusaha dengan maksimal dalam menciptakan inovasi baru agar dapat menyediakan sumber-sumber informasi dan dapat memenuhi semua kebutuhan informasi yang diinginkan masyarakat di tengah pandemi ini. Sebagaimana contoh yang dapat kita lihat bahwa Perpustakaan Nasional (Perpusnas) yang sudah lama memiliki layanan perpustakaan digital, yang dimana layanan perpustakaan digital tersebut berupa aplikasi yang bernama Ipusnas, dengan aplikasi Ipusnas sendiri masyarakat dapat dengan mudah mengakses dan menelusuri informasi-informasi sesuai dengan yang dicari, relevan dan akurat karena di di dalam aplikasi Ipusnas tersebut sudah tersedia berbagai macam koleksi bahan bacaan berbentuk digital yang dimiliki oleh Perpustakaan Nasional (Perpusnas).

Aplikasi Ipusnas ini memiliki banyak manfaat yang bisa diperoleh masyarakat karena sejak pandemi melanda, banyak perpustakaan yang dihimbau untuk melakukan pekerjaan di rumah dan menutup sementara seluruh kegiatan pelayanan untuk masyarakat umum. Selain itu, banyak masyarakat pula termasuk pelajar dan mahasiswa terpaksa melakukan pembelajaran jarak jauh (PJJ) dan meniadakan pembelajaran secara tatap muka serta beralih menjadi pembelajaran melalui online atau yang sering disebut daring seperti menggunakan aplikasi Zoom, Google Meet, Google Classroom, WhatsApp, dan sebagainya. Hal ini juga tentu mengakibatkan banyak dari masyarakat yang kebingungan dalam mencari informasi yang dibutuhkan baik berupa koleksi buku maupun yang lainnya, untuk itu dengan adanya aplikasi Ipusnas milik Perpustakaan Nasional (Perpusnas) ini akan sangat bermanfaat dalam membantu masyarakat guna 
mendapatkan berbagai informasi secara efektif dan efisien serta dapat diakses kapan dan dimana saja tanpa terbatasi oleh waktu.

Namun pada dasarnya tidak semua perpustakaan sudah memiliki atau melakukan inovasi baru terhadap pelayanan perpustakaan yang dimiliki, hal ini disebabkan banyak perpustakaan yang masih belum dapat beradaptasi terkait adanya pandemi covid-19 yang datang secara mendadak. Selain itu, adapula perpustakaan yang masih berupaya untuk menciptakan sebuah inovasi baru terhadap pelayanannya agar dapat melayani masyarakat atau pengguna perpustakaan baik itu secara langsung ataupun secara online melalui layanan digital. Salah satu perpustakaan daerah yang masih berupaya dalam menciptakan inovasi baru terhadap layanan perpustakaan adalah Dinas Kearsipan dan Perpustakaan Kabupaten Cianjur, menurut hasil yang diperoleh penulis dari penelitian ini bahwa Dinas Kearsipan dan Perpustakaan Kabupaten Cianjur masih mengupayakan untuk menciptakan inovasi baru dalam melayani masyarakat atau pengguna perpustakaan di tengah pandemi covid-19 ini.

Akan tetapi, dikarenakan masih memiliki berbagai keterbatasan yang dimiliki perpustakaan dalam aspek sarana dan prasarana yang dimana Dinas Kearsipan dan Perpustakaan Kabupaten Cianjur sendiri sejauh ini baru memiliki database online public acces catalog (OPAC) yang hanya dapat diakses untuk mencari data terhadap koleksi yang dimiliki serta belum memiliki layanan yang berbasis digital. Oleh sebab itu, guna memenuhi kebutuhan masyarakat yang semakin meningkat dan beragam di tengah pandemi yang sedang berlangsung ini maka pustakawan Dinas Kearsipan dan Perpustakaan Kabupaten Cianjur hanya dapat mengarahkan kepada pemustaka dengan merekomendasikan akses layanan digital yang telah dimiliki oleh Perpustakaan Nasional yang berupa aplikasi Ipusnas dan aplikasi CANDIL atau Maca Dina Digital Library milik Dinas Perpustakaan dan Kearsipan Daerah Provinsi Jawa Barat (Dispusipda Jabar).

Untuk dapat mengakses aplikasi Ipusnas dan Candil, masyarakat atau pengguna perpustakaan dapat mengikuti alur atau mekanisme seperti yang ada pada gambar di atas yaitu dengan cara menginstall terlebih dahulu aplikasinya kemudian mendaftarkan diri sebagai anggota dengan melakuan registrasi apabila masyarakat atau pengguna perpustakaan belum memiliki akun. Setelah berhasil melakukan pendaftaran, maka masyarakat mampu mengakses dan memperoleh sumber-sumber informasi yang berbentuk 
elektronik seperti e-book atau e-journal dan sebagainya dengan bebas kapan pun dan dimana pun sesuai dengan keinginannya tanpa harus datang secara langsung ke perpustakaan. Selain itu, dengan adanya aplikasi layanan digital tersebut masyarakat atau pengguna perpustakaan tidak perlu merasa kebingungan lagi dalam mencari sumber-sumber referensi akibat penutupan layanan perpustakaaan yang diperpanjang.

\section{KESIMPULAN}

Berdasarkan hasil penelitian yang telah penulis uraikan di atas, maka dapat disimpulkan bahwa adanya pandemi covid-19 saat ini telah mengubah seluruh tatanan kehidupan masyarakat yang dimana mengharuskan masyarakat untuk mematuhi protokol kesehatan dengan selalu menggunakan masker, giat mencuci tangan dengan sabun, dan selalu menjaga jarak dengan orang lain serta tetap berada di rumah masingmasing dalam rentang waktu yang panjang serta mengurangi kegiatankegiatan diluar rumah yang tidak begitu penting. Pemerintah Indonesia pun memberlakukan sebuah kebijakan baru yang bernama Pembatasan Sosial Berskala Besar (PSBB) sebagai bentuk upaya mencegah penyebaran virus corona. Pandemi covid-19 ini juga telah mempengaruhi terhadap berbagai aspek salah satunya yaitu bagi perpustakaan daerah. Perpustakaan daerah merupakan salah satu fasilitas khusus yang telah disediakan pemerintah guna membantu masyarakat dalam memenuhi kebutuhannya terhadap informasi, oleh karena itu siapapun dapat memanfaatkan layanan perpustakaan.

Pada prinsipnya setiap perpustakaan memiliki sebuah kebijakannya masing-masing dalam melayani masyarakat atau penggunanya, Dinas Kearsipan dan Perpustakaan Kabupaten Cianjur memiliki beberapa kebijakan termasuk dalam layanan sirkulasi yang dimana menggunakan sistem pelayanan open access. Di tengah pandemi ini Dinas Kearsipan dan Perpustakaan Kabupaten Cianjur dengan terpaksa harus menghentikan segala jenis aktivitasnya dan menutup sementara layanan perpustakaan dikarenakan dengan adanya kebijakan work from home (WFH) yang diterapkan oleh pemerintah sehingga menuntut para pegawai perpustakaan untuk bekerja dari rumah dan melakukan berbagai kegiatannya secara daring serta tidak dapat memberikan pelayanan perpustakaan secara optimal dalam memenuhi kebutuhan pemustaka terhadap informasi yang ada di perpustakaan. Setelah adanya pandemi covid-19 Dinas Kearsipan dan Perpustakaan Kabupaten Cianjur hanya 
dapat melakukan beberapa kegiatan yang terbatas, berbeda dengan sebelum adanya pandemi ini dimana rutin melakukan berbagai kegiatan seperti melaksanakan kegiatan layanan perpustakaan keliling khusus untuk warga masyarakat yang berada di wilayah yang jauh dengan jangkauan layanan perpustakaan umum. Dinas Kearsipan dan Perpustakaan Kabupaten Cianjur juga telah menjadi bagian dari fasilitator dalam beberapa kegiatan masyarakat seiring dengan berkembangnya paradigma perpustakaan yang berbasis inklusi sosial.

Pada masa pandemi covid-19 tuntutan akan kebutuhan informasi yang dimiliki oleh masyarakat semakin besar dan beragam, menyebabkan perpustakaan pun harus berusaha dengan maksimal dalam menciptakan inovasi baru dengan menerapkan pelayanan yang berbasis teknologi informasi seperti merubah sistem pelayanan yang berasal dari manual menjadi sistem layanan digital. Namun Dinas Kearsipan dan Perpustakaan Kabupaten Cianjur sendiri masih mengupayakan untuk menciptakan inovasi baru agar dapat melayani masyarakat atau pengguna perpustakaan di tengah pandemi yang sedang berlangsung. Hal ini dikarenakan terbatasnya sarana dan prasarana serta belum memiliki layanan berbasis digital, sehingga pustakawan Dinas Kearsipan dan Perpustakaan Kabupaten Cianjur hanya dapat mengarahkan kepada pemustaka dengan merekomendasikan akses layanan digital yang telah dimiliki oleh Perpustakaan Nasional yang berupa aplikasi Ipusnas dan aplikasi CANDIL atau Maca Dina Digital Library milik Dinas Perpustakaan dan Kearsipan Daerah Provinsi Jawa Barat (Dispusipda Jabar). Diharapkan seluruh perpustakaan dapat terus memberikan berbagai macam inovasi layanan sesuai dengan tingkat kebutuhan informasi pemustaka yang semakin banyak dan beragam, dengan memanfaatkan layanan yang berbasis teknologi sehingga kebutuhan pemustaka pun dapat terpenuhi dengan baik.

\section{DAFTAR RUJUKAN}

Arista, R. (2019). KUALITAS PELAYANAN PERPUSTAKAAN DAERAH KABUPATEN SUBANG. Dinamika : Jurnal Ilmiah Ilmu Administrasi Negara, 6(4), 280-288.

Ayuningtyas, T. (2015). Kualitas Layanan di Perpustakaan Umum Kota Madiun (Studi Deskriptif tentang Kualitas Layanan dengan Menggunakan LibQual di Perpustakaan Umum Kota Madiun). Libri- 
Net, 4(1), 120-133.

Azanella, L. A. (2021). Simak, Ini Cara Membedakan Gejala Covid-19, Flu, dan Influenza. KOMPAS.Com. Diakses 23 November, 2020, dari https://www.kompas.com/tren/read/2021/01/24/130500065/simak-inicara-membedakan-gejala-covid-19-flu-dan-influenza?page=all

Lies, U., Khadijah, S., Rukmana, E. N., Ningsih, A. S. R., Ariyan, P. M., Angelina, R. B., Syifa, R. N., \& Yuliani. (2020). Wisata Virtual Pada Perpustakaan Digital Selama Masa Pandemi Covid-19. Tornare Journal of Sustainable Tourism Research, 2(3), 63-77.

Meilisa, V. F. (2019). DEVELOPMENT COLLABORATION INTERLIBRARY COLLECTION IN UNIVERSITY. Jurnal Pustaka Ilmiah, 5(1), 866-877.

MS, Z. H., \& Rizaldi, A. (2020). MERESPON NALAR KEBIJAKAN NEGARA DALAM MENANGANI PANDEMI COVID 19 DI INDONESIA. Jurnal Ekonomi Dan Kebijakan Publik Indonesia, 7(1), $36-53$.

Prabowo, A., \& Heriyanto. (2013). ANALISIS PEMANFAATAN BUKU ELEKTRONIK ( E-BOOK ) OLEH PEMUSTAKA DI PERPUSTAKAAN SMA NEGERI 1 SEMARANG. Jurnal Ilmu Perpustakaan, 2(2), 1-9.

Ristyawati, A. (2020). Efektifitas Kebijakan Pembatasan Sosial Berskala Besar Dalam Masa Pandemi Corona Virus 2019 oleh Pemerintah Sesuai Amanat UUD NRI Tahun 1945. Administrative Law \& Governance Journal, 3(2), 240-249.

Suharso, P., Arifiyana, I. P., \& Wasdiana, M. D. (2020). Layanan

Perpustakaan Perguruan Tinggi dalam Menghadapi Pandemi Covid19. ANUVA, 4(2), 271-286.

Sukaesih, \& Winoto, Y. (2019). Dasar-Dasar Pelayanan Perpustakaan (I). Kebumen: CV. Intishar Publishing. 